UDK: 352.9.07

POSLOVNA EKONOMIJA

BUSINESS ECONOMICS

Godina XV

Originalni naučni rad

Broj 1

Str $20-31$

doi: 10.5937/poseko19-32709

Viktória Csizmadiáné Czuppon, PhD, Associate Professor ${ }^{1}$

University of Pannonia, Veszprém, Hungary

Faculty of Business and Economics,

Department of Business Economics

Milena Galetin, PhD, Assistant Professor ${ }^{2}$

Educons University, Sremska Kamenica - Novi Sad,

Faculty of Business Economics

Bela Muhi, PhD, Associate Professor ${ }^{3}$

Educons University, Sremska Kamenica - Novi Sad,

Faculty of Business Economics

\title{
CITIZEN PARTICIPATION IN THE DEVELOPMENT OF PUBLIC POLICIES IN VESZPRÉM COUNTY AND THE BALATON REGION ${ }^{4}$
}

\begin{abstract}
The participation of citizens in decision-making process at the local level is a prerequisite for the existence of a democratic society. The importance of local producers' involvement in this process is significant because they contribute to the development of the local community and improve its living conditions. The authors deal with the questions of how the local producers in the Veszprém County and the Balaton Region are familiar with these rights, to what extent they use them and what the obstacles for citizen participation in public life at the local level are. In order to
\end{abstract}

\footnotetext{
${ }^{1}$ czuppon.viktoria@gtk.uni-pannon.hu

2 milena.galetin@educons.edu.rs

3 muhi.bela@gmail.com

4 This research was realised in the framework of the EFOP-3.6.2-16-2017-00017 Sustainable, intelligent and inclusive regional and city models project which is subsidised by the European Union and Hungary and co-financed by the European Social Fund.
} 
examine the whole problem, the survey also includes the representatives of local authorities. This research consists of three parts. After introduction and legislative review, in the second part the results of the survey are presented. The combination of theoretical analysis and empirical research that is characteristic for social sciences is used. Finally, in the last part, recommendations for the improvement of the participation of local citizens in creating the public policies at the local level in the mentioned region are presented.

Key words: citizen participation, decision-making process at local government level, local producers/communities, creation of public policies - local level, Veszprém County/Balaton Region

\section{INTRODUCTION}

It is widely accepted that citizens can exercise their right to participate in the policy-making at the local level in two ways: directly and indirectly. In this context, a direct involvement means citizen participation through traditional methods - referendum, citizen initiatives and public meetings, as well as through innovative methods - citizen panels, focus groups or electronic debates. Indirect citizen participation refers to taking part through their freely chosen representatives. Citizen participation in shaping and implementing public policies at state and local level is regarded as a critical ingredient of participatory democracy (Golubović, 2013, p. 81).

In the article we deal with the direct participation of citizens in the decision-making process. That implies various citizens' activities in the decision-making process of public importance that thus directly affect the quality of their lives (within a narrow or wider community they live) (Brnjas \& Radovanović Dumonjić, 2013, p. 10). It is considered that participatory democracy is a necessary complement to representative democracy.

Namely, it has been observed that the shortcomings of representative democracy and the rule of political parties have led to the worrying apathy of the citizen, as well as the growing complexity of the governance process in contemporary societies (Vukelic, ed., 2006, p. 1). In that regard participatory democracy could have positive impact which involves interest in and willingness for cooperation of all relevant subjects, i.e. local government bodies, on the one hand, and citizens on the other (Brnjas \& Radovanović Dumonjić, 2013, p. 12).

In short, participatory democracy contributes to the effectiveness of 
representative democracy in several ways:

- enables constant participation of citizens in the political process, not only during the elections

- enables citizens to defend their legitimate interests in the process of adopting public policies

- contributes to the open and transparent work of the executive and representative authorities and makes that work closer to the citizens

- contributes to the quality of adopted public policies and their effective implementation. Some empirical researches indicate that citizens are more willing to participate in the implementation of the particular public policy if they participated in the process of its adoption - even when their proposals are not fully accepted.

- provides easier control over the implementation of adopted public policies (Golubović \& Velat, 2009, pp. 8-9) ${ }^{5}$.

Concerning citizen participation itself, it is possible to make distinction between the following forms, from lower to higher level of participation: (a) informing - informing citizens about the work, plans and intentions of a representative of local authorities and providing other information of public importance; (b) consultation - citizen participation in determining local community priorities through citizen panels, public debates, consultations via electronic media and the Internet; (c) suggestions - petitions, individual proposals, complaints, forms of public criticism, protests, peaceful gatherings, demonstrations, etc., (d) participation in decision-making referendum, citizen initiative ${ }^{6}$.

In respect of legal framework relating to citizen participation in Hungary, it is necessary to mention that the Treaty of Lisbon prescribes that the European Union is based on the principles of political democracy (power sharing, multi-party system) and representative democracy (citizen participation in policy-making). Accordingly, citizens' participation in the creation of public policies represents the constitutional value of the Union and binds its members. In Consolidated version of the Treaty on European Union $^{7}$ it is prescribed as follows:

\footnotetext{
${ }^{5}$ For the summary of advantages and disadvantages of citizen participation in decisionmaking process see: Dubravka Jurlina Alibegović, Sunčana Slijepčević, Attitudes towards Citizen Participation in the Local Decision-making Process: A Comparative Analysis, The Institute of Economics, Zagreb, 27 (2018), No. 1, p. 158.

${ }^{6}$ See: Jelisaveta Vukelić, Citizen Participation at the Local Level of Government in Serbia Sociologija, Vol. LI (2009), N 3, p. 298.

${ }^{7}$ Consolidated version of the Treaty on European Union, Official Journal of the European Union, C 326/21.
} 


\section{TITLE II \\ PROVISIONS ON DEMOCRATIC PRINCIPLES}

Article 10

1. The functioning of the Union shall be founded on representative democracy.

2. Citizens are directly represented at Union level in the European Parliament. Member States are represented in the European Council by their Heads of State or Government and in the Council by their governments, themselves democratically accountable either to their national Parliaments, or to their citizens.

3. Every citizen shall have the right to participate in the democratic life of the Union. Decisions shall be taken as openly and as closely as possible to the citizen ${ }^{8}$.

In that regard it is important to point out Recommendation CM/Rec (2018)4 of the Committee of Ministers to member States on the participation of citizens in local public life (Adopted by the Committee of Ministers on 21 March 2018 at the $1311^{\text {th }}$ meeting of the Ministers' Deputies) and the Congress of local and regional authorities - Council of Europe Resolution no. 326/11- Citizen participation at local and regional level in Europe.

Finally, citizen participation in legislative processes is a constitutional right in Hungary:

\section{Article XXIII}

7. Every person entitled to vote in elections of Members of Parliament shall have the right to participate in national referenda. Every person entitled to vote in elections of local representatives and mayors shall have the right to participate in local referenda.

\section{Local Governments}

Article 31

(1) In Hungary local governments shall function to manage local public affairs and exercise local public power.

(2) Local referendums may be held on any matter within the functions and powers of the local government, as provided for by an Act.

Based on the above, it could be concluded that the legal regulation concerning the participation of citizens in Hungary is the same as in other contemporary European societies ${ }^{9}$.

\footnotetext{
${ }^{8}$ See art. 11, Consolidated version of the Treaty on European Union and art. 20 and 24, Consolidated version of the Treaty on the Functioning of the European Union, Official Journal of the European Union, C 115/57.

9 See more: Erika Steiner, Introduction to the Hungarian Local Government System, available
} 


\section{CITIZEN PARTICIPATION IN THE DEVELEOPMENT OF PUBLIC POLICIES IN VESZPRÉM COUNTY AND THE BALATON REGION}

\section{Methods and Methodology}

The complexity of the subject of the research required a combination of theoretical analysis and empirical research. When it comes to theoretical analysis, a descriptive legal research, targeted and comparative methods of research were used. Empirical research was based on indicative methods of sample: interview with the citizens/local producers in order to get the data which presents how familiar the citizens are with the normative framework for their participation in the process of creating public policies and to what extent they have participated in it. This part of the research included the preparation of a questionnaire on the barriers for greater citizen participation in the process of creating public policies. There were 75 local producers and 11 representatives of the local government of Veszprém county/Balaton region who filled in the surveys (including mayor and vice-mayor of Veszprém). The use of this combined methodology enabled the appropriate verification of the obtained data.

\section{Survey - Results}

Among the local producers who filled in the survey the most common occupations/professions were entrepreneurs and farmers, but there were also beekeepers, butchers, confectioners, technologists, teachers, medical workers, administration workers, hairdressers, retirees, artisans, managers, students, workers in rural tourism, engineers etc.

The following questions were evaluated by local producers and representatives of local authorities by grades from 1 to 5 .

We examined if they knew that there was participation of citizens in public life at the local level, and that they had the right to manage the local community. Medium level of knowledge was demonstrated by local producers. However, $14 \%$ of the local producers gave the lowest grades (1 and 2) and $24 \%$ gave grade 3 . That indicates the need for improvement. As expected, representatives of local authorities are familiar with these rights of citizens/local producers.

at:http://www.manorka.net/uploads/images/Kiadv\%C3\%A1nyok/kiadvany_onk_rendsz_eng. pdf. 
Graph 1.

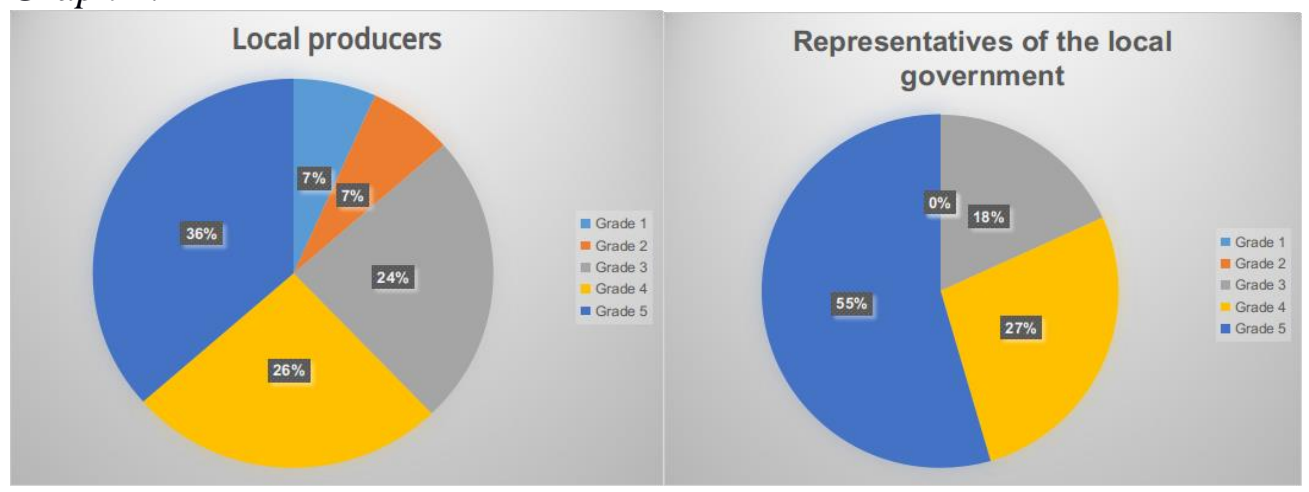

Source: Authors

The next question asked if they were content with the quality of the relations between citizens and local authorities. There is a difference in answers here: $37 \%$ of local producers considered that the relationship is good (grades 4 and 5), comparing to 73\% of government representatives. Local producers are much more dissatisfied with the quality of the relations between citizens and local authorities.

\section{Graph 2.}

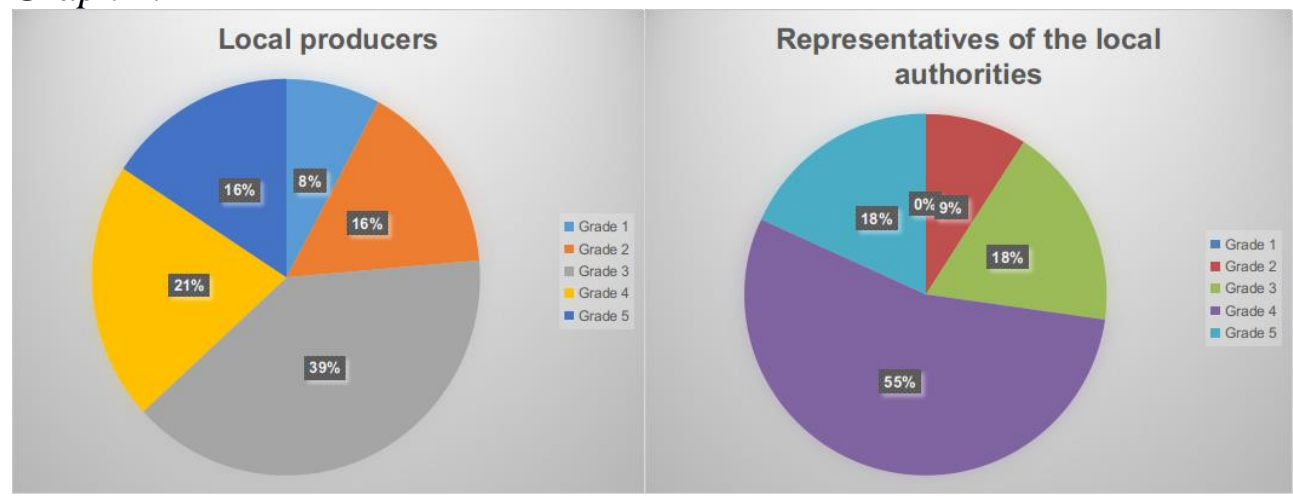

Source: Authors

On the issue of them having any information about the work and plans of local authorities and the situation in the local community, $17 \%$ of local producers gave the lowest grade (1 and 2). This segment should also be improved. On the other side, over $90 \%$ of representatives of local authorities gave the best grade (4 and 5). 


\section{Graph 3.}

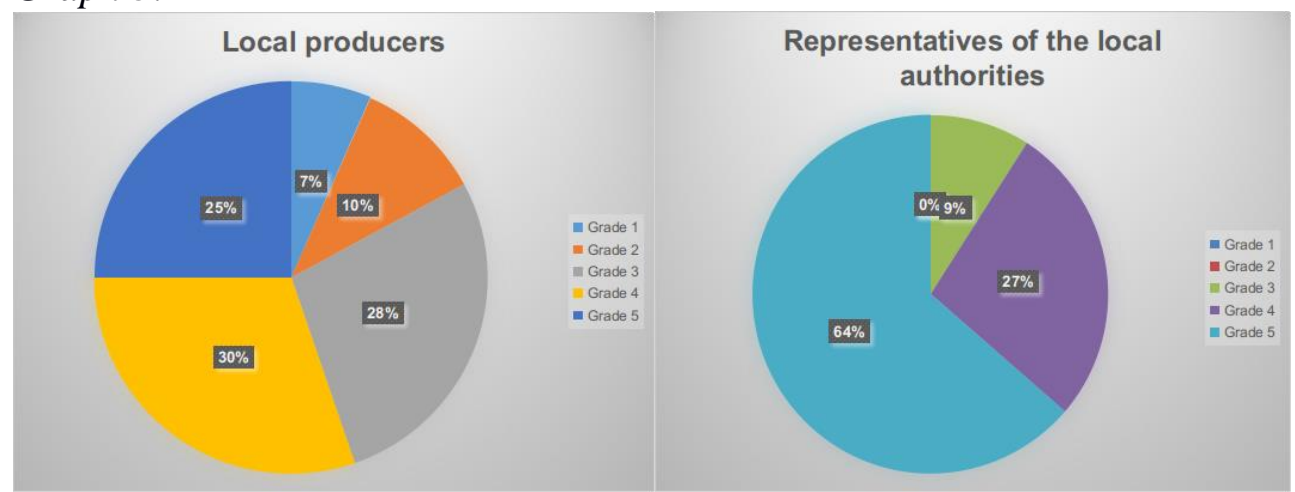

Source: Authors

Very interesting information was obtained when we questioned if the local producers/representatives of local authorities thought that their suggestions, remarks and critics could influence decision-making at the local level. Nearly $30 \%$ of local producers do not think they have any impact (or think they have very little impact). If we have in mind that another $29 \%$ of local producers gave grade 3 , we could conclude that this is one of the most serious problems when citizens' participation in decision-making is concerned because there is no mutual trust and faith necessary in this process. On the other hand, representatives of local authorities do not think that their suggestions, remarks and critics can influence decision-making on the local level as expected. Even $18 \%$ of local government representatives think they have little or no impact at all. We assume that this is due to the impact of politics at the national level.

Graph 4.

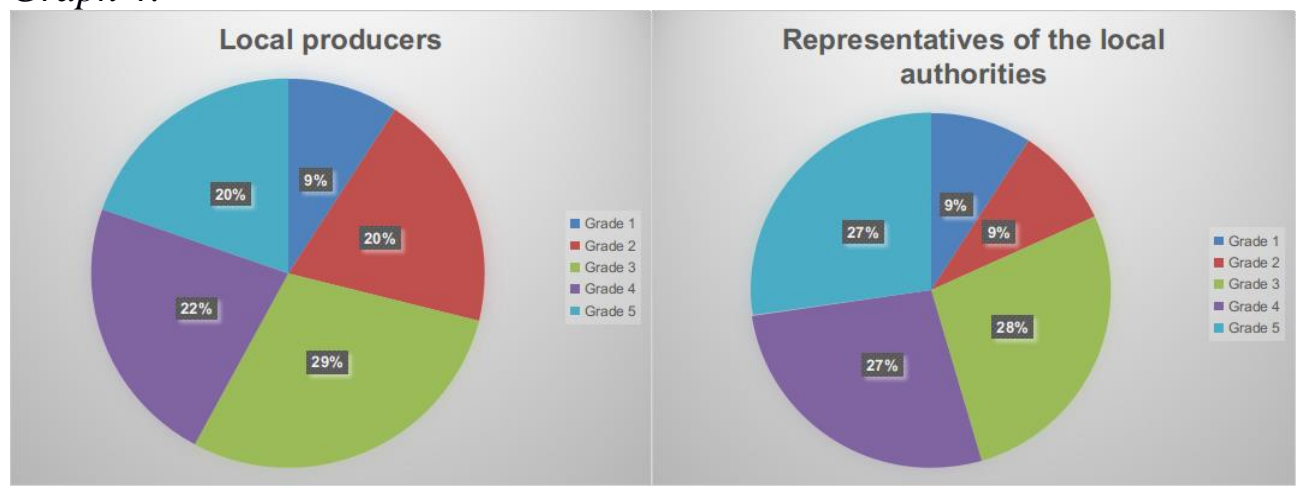

Source: Authors

According to the results of the research, local producers are generally not content with the taxation system that applies to their products and 
services $-28 \%$ gave grades 1 and 2 (29\% gave grade 3$)$.

Graph 5.

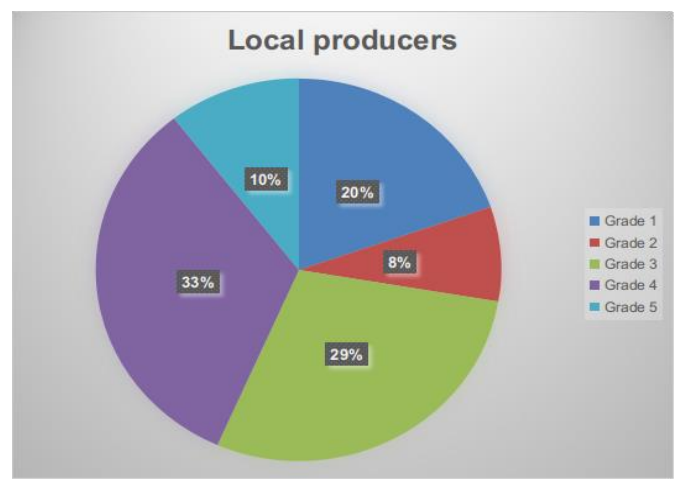

Source: Authors

Almost all local producers are familiar with referendum, and in large numbers with citizen initiative and public meeting. They are the least familiar with citizens panels $(14,6 \%)$ and electronic debates $(30,6 \%)$. Therefore, all forms of citizen participation in decision-making process should be promoted, citizens should be informed and encouraged to use them.

Graph 6.

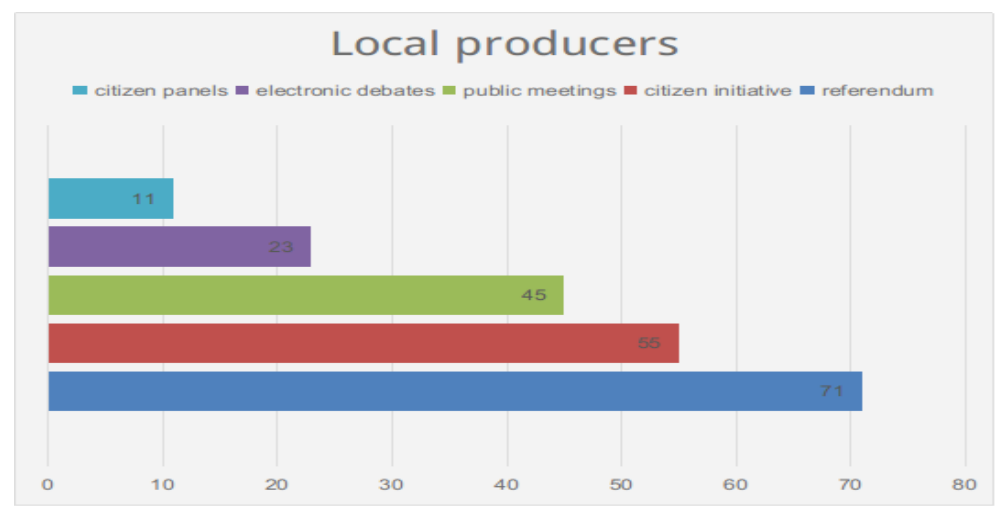

Source: Authors

Local producers and representatives of local authorities have very similar answers regarding the opinions concerning the obstacles for citizen participation in public life at the local level and about the most important obstacles for the improvement of citizen participation in public life at the local level. The most frequent answers were indifference, unconcern of the local citizens, lack of information, lack of time, laziness, non-transparency, and politics. Local producers added to this list by mentioning lack of money at the local level, corruption, the fact that decision makers at the local level 
do not deal with the problems of the citizens and that the state-level policies have a significant impact on decision-makers at the local level.

Finally, the last two questions reflect significant difference between local producers and local government representatives. Namely, the question of how trustworthy they considered most people was answered as follows $52 \%$ of local producers answered no, and 33\% answered yes, in contrast to $27 \%$ of government representatives who answered no and $55 \%$ who answered yes. We could assume that it is due to the fact that local government representatives are not in the market in the way local producers are that they have such feelings and opinions.

Graph 7.

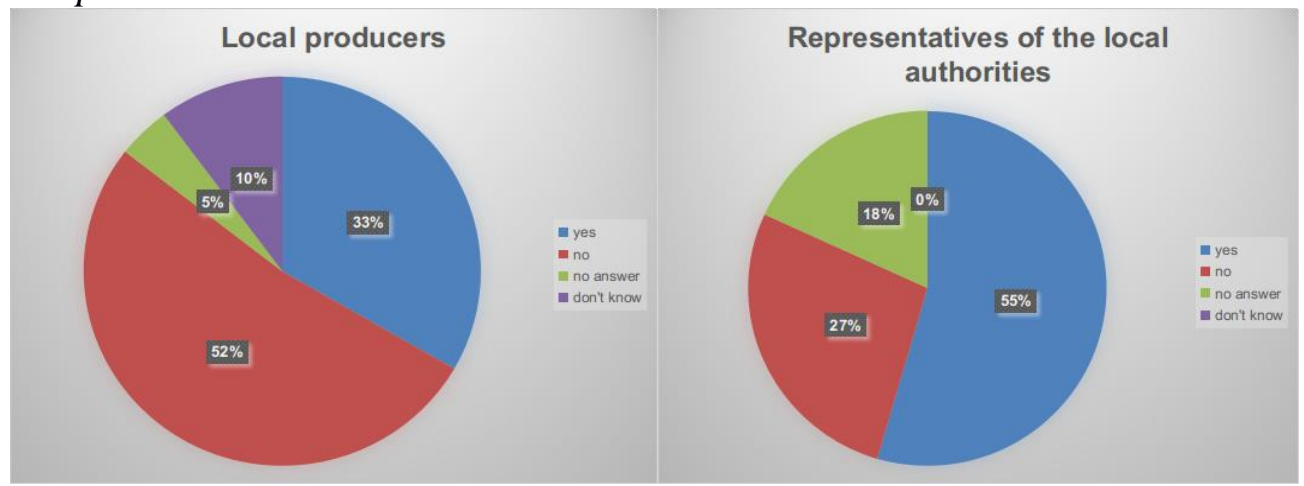

Source: Authors

We believe that, for the same reason, answers to the last question were similar. Namely, we wanted to know if they thought that they needed to be cautious about working with people. The huge percentage $(86 \%)$ of local producers' answers were affirmative, unlike $27 \%$ of local government representatives.

Graph 8.

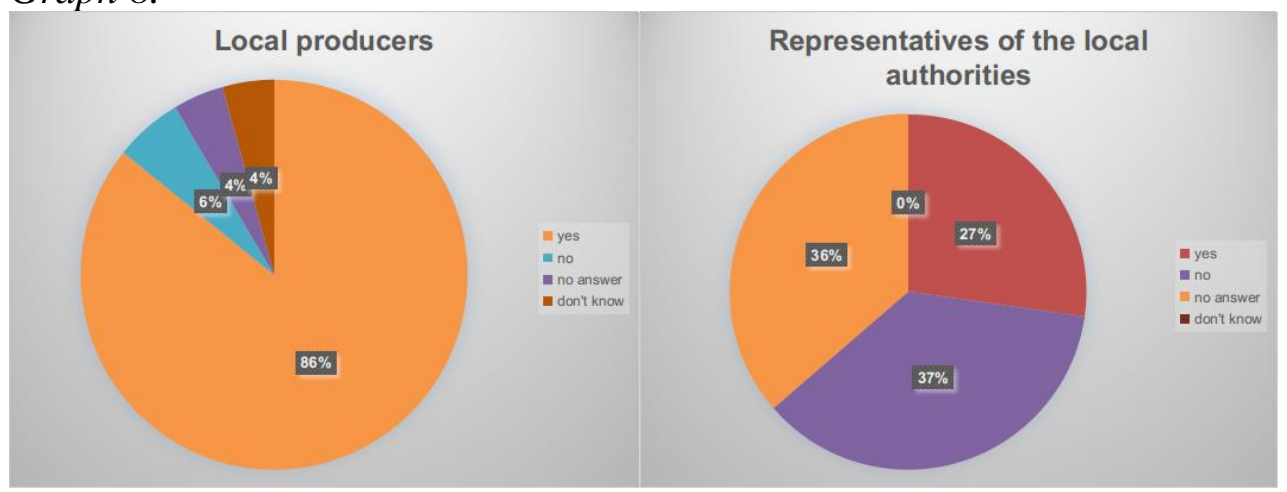

Source: Authors 


\section{CONCLUSION AND RECOMMENDATIONS}

Most of the conclusions are already presented in the part referring to the analysis of the survey. After a short review, recommendations for improving the position of local producers in the Veszprém County and the Balaton Region through citizen participation in the creation of public policies will be suggested.

Firstly, it is important to emphasize that legal and institutional frameworks in the mentioned region are typical of a modern democratic European society. The level of knowledge regarding participation of citizens in public life in the local community in the Veszprém County and the Balaton Region is medium. $38 \%$ of local producers gave grades $1-3$, which indicates the need for improvement of this segment of citizen participation. Concerning the quality of the relations between citizens and local authorities, the results of the survey show that citizens are much more discontent. However, more worrying is the fact that $17 \%$ of the local producers do not have any information/have very poor information about the work and plans of local authorities and the situation in the local community. Likewise, we are concerned about the fact that almost $30 \%$ of citizens think they don't have influence on decision-making process (grade 1 and 2). Both local producers and representatives of local authorities in the Veszprém County and the Balaton Region pointed out the following problems: indifference, unconcern of the local citizens, lack of information, lack of time, laziness, lack of money at the local level, non-transparency, politics.

On the basis of the aforementioned, we consider that the following recommendations will contribute to greater and better participation of citizens in the creation of public policies. On one side, it is necessary to raise awareness of citizens that their participation is necessary and desirable. This could be achieved through the organization of workshops, trainings, seminars and other relevant educational and interactive activities. All kinds of local media are important in this process and the Internet and usage of social networks could be important source of information for this purpose, especially among younger population. Therewithal, it is necessary to raise awareness of the representatives of local authorities that citizen participation is necessary and desirable. The employees in local government should be well informed and educated about the importance of the local citizens' participation and give necessary support to citizens when exercising their rights. Both citizens and local government representatives should act jointly and with the same broader goal - the prosperity of the local community. Only in that way will the citizens' participation in the creation of public policies at the local level get its true meaning. 


\section{REZIME \\ UČEŠĆE GRAĐANA U KREIRANJU JAVNIH POLITIKA U ŽUPANIJI VESPREM I BALATON REGIONU}

Učešće građana u procesu donošenja odluka na lokalnom nivou je jedan od neophodnih uslova za postojanje demokratskog društva. Značaj uključivanja lokalnih proizvođača u ovaj proces je veoma bitan jer su oni ti koji doprinose razvoju lokalne zajednice i poboljšanju uslova za život i rad u njoj. Autori se u radu bave pitanjima koliko su lokalni proizvođači u županiji Vesprem i Balaton regionu upoznati sa pravom da aktivno učestvuju u kreiranju javnih politika na lokalnom nivou, u kojoj meri koriste ova svoja prava i sa kojim se preprekama pri tom suočavaju. Kako bi se problem sagledao u celini, istraživanjem su obuhvaćeni kako lokalni proizvođači/građani, tako i predstavnici lokalnih vlasti. Sam rad se sastoji iz tri dela. Nakon uvoda i osvrta na pravnu regulativu, u drugom delu su prikazani rezultati sprovedene ankete/upitnika. Preporuke za unapređenje učešća građana u kreiranju javnih politika na lokalnom nivou, u pomenutom regionu, su iznete u poslednjem delu rada.

Ključne reči: učešće građana, participacija građana u donošenju odluka na lokalnom nivou, lokalni proizvođači/zajednice, kreiranje javnih politika na lokalnom nivou, županija Vesprem/Balaton region

\section{REFERENCES}

1. Brnjas, Z., Radovanović Dumonjić, M., Promocija dobrih praksi učešća građana u lokalnom budžetiranju u gradovima i opštinama u Srbiji, Misija OEBS u Srbiji, 2013.

2. Vukelić, Z., (ed.), Neposredno učešće građana u javnom životu na lokalnom nivou; Beograd: Stalna konferencija gradova i opština, 2006 (Beograd: Dosije).

3. Golubović, D., The Role of Citizen Participation in the Reform of Public Administration, Business Economics, 2013/1, pp. 79-96.

4. Golubović, D., Velat, D., Učešće građana i građanki u procesu izrade i primene zakona i drugih instrumenata javnih politika, Beograd: Građanske inicijative, 2009.

5. Vukelić, J., Citizen Participation at the Local Level of Government in Serbia Sociologija, Vol. LI (2009), N 3, pp. 291-312.

6. Consolidated version of the Treaty on European Union, Official Journal of the European Union, C 326/21. 
7. Consolidated version of the Treaty on the Functioning of the European Union, Official Journal of the European Union, C 115/57.

8. Recommendation $\mathrm{CM} / \operatorname{Rec}(2018) 4$ of the Committee of Ministers to member States on the participation of citizens in local public life (Adopted by the Committee of Ministers on 21 March 2018 at the $1311^{\text {th }}$ meeting of the Ministers' Deputies).

9. Congress of local and regional authorities- Council of Europe Resolution no. 326/11- Citizen participation at local and regional level in Europe.

10. Hungary's Constitution, 2011; available at: https://www.constituteproject.org/constitution/Hungary 2011.pdf.

11. Steiner, E., Introduction to the Hungarian Local Government System, available

at: http://www.manorka.net/uploads/images/Kiadv\%C3\%A1nyok/kiadvany _onk_rendsz_eng.pdf.

12. Jurlina Alibegović, D., Slijepčević, S., Attitudes towards Citizen Participation in the Local Decision-making Process: A Comparative Analysis, The Institute of Economics, Zagreb, 27 (2018), No. 1, pp. 155175.

Ovaj rad je primljen 10.06.2021., a na sastanku redakcije časopisa prihvaćen za štampu 28.06.2020. godine. 